\title{
ANALISIS PENERAPAN MANAJEMEN RISIKO PEMBIAYAAN PADA LEMBAGA PEMBIAYAAN SYARIAH
}

\author{
A. Syathir Sofyan*
}

\begin{abstract}
This research discusses financing risk management in sharia financing institutions. Financing risk is a risky risk and can lead to systemic risk one of which occurred the global financial crisis. Sharia financing institutions are identical with those risks, so that the application of proactive risk management should be done so as not to be affected. The purpose of this research is to know the risk management of financing at PT XYZ, which in this research is qualitative decriptive. Data analysis used is data reduction, data presentation, verification andconclusion. The results of this study indicate that the implementation of risk management of financing at PT XYZ is categorized not good enough. this means that to create financing risk management it is necessary to apply a reliable and consistent risk management system. Seeing the results of the research that during the period 2014 to 2016 has increased the value of NPF, which requires companies to act quickly to mitigate the value of NPF ratio Keywords: Shariah Financing Institution, Risk Management, Financing Risk, and Financing risk management.
\end{abstract}

\section{A. PENDAHULUAN}

Krisis ekonomi Indonesia yang ditandai dengan beban utang luar negeri yang besar dan anggaran yang defisit telah melipatgandakan jumlah penduduk miskin. Akar masalah krisis fiskal pada tahun 2008 adalah adanya krisis di sektor perbankan Amerika Serikat sehingga menimbulkan banyaknya ketimpangan sosial di 
masyarakat. Krisis tersebut diawali dengan kejatuhan nilai aset sektor perumahan yang merambat kepada terjadinya gagal bayar debitur subprime mortgage. Bernula dari kebijakan pemerintah yang memberikan kemudahan syarat pengajuan pinjaman yang didukung tren jangka panjang peningkatan harga rumah mendorong praktik penyaluran kredit yang berisiko tinggi dengan berharap dapat melakukan refinancing pada suku bunga yang lebih rendah. ${ }^{186}$

Sama halnya di Amerika, Industri keuangan di Indonesia memang mengalami perkembangan pesat terutama Lembaga Jasa Keuangan Non Bank (LJKNB). Hal ini tentu mengakibatkan semakin kompleksnya risiko bagi kegiatan usaha LJKNB. Risiko ini terkait dengan kejadian kriris keuangan global tahun 2008. Namun, lembaga keuangan sendiri dapat mengambil tindakan untuk mengurangi hal tersebut. ${ }^{187}$ Untuk mengurangi risiko, maka usaha yang dilakukan adalah penerapan manajemen risiko yang proaktif sehingga lembaga keuangan dapat memiliki keberlangsungan usaha jangka panjang. ${ }^{188}$ Menurut Islamic Fnancial Institutions (IFI) ada lima komponen utama dalam pembagian risiko di lembaga keuangan Islam yaitu transaction

\footnotetext{
${ }^{186}$ Bank Indonesia, Buku Laporan Perekonomian Indonesia tahun 2008, (Jakarta: Direktorat Riset Ekonomi dan Kebijakan Moneter Bank Indonesia, 2008), h. 63-64.

${ }^{187}$ Siti Khadijah Ab Manan and Muhammad Hakimi Bin Mohd Shafi ai, 'Risk Management of Islamic Microfinance (IMF) Product by Financial Institutions in Malaysia", (Makalah yang disajikan pada International Accounting And Business Conference (IABC), Procedia Economics and Finance 31, 2015), h. 84. http://ac.els-cdn.com/S221256711501134X/1-s2.0$\underline{\text { S221256711501134X-main.pdf? tid=d7e9a46a }}$ $-6064-11 \mathrm{e} 6-\mathrm{b} 117-$ 00000aab0f6b\&acdnat=1470989871 99dc5b46eba9cb909212c61c 0304d392 (Diakses pada tanggal 10 Agust us 2016).

${ }^{188}$ Siti Khadijah Ab Manan and Muhammad Hakimi Bin Mohd Shafi ai,"Risk Management of Islamic Microfinance (IMF) Product by Financial Institutions in Malaysia", h. 85
} 
risks, business risks, tresuary risks, governance risks, dan systemic risks. ${ }^{189}$ Dari kelima komponen ini terbagi lagi beberapa risiko yang tertera di bawah ini.

Tabel 1

Profil Risiko dalam Operasi Islamic Fnancial Institutions (IFI)

\begin{tabular}{|l|l|l|l|l|}
\hline Transaction & $\begin{array}{l}\text { Business } \\
\text { risks }\end{array}$ & $\begin{array}{l}\text { Tresuary } \\
\text { risks }\end{array}$ & $\begin{array}{l}\text { Governance } \\
\text { risks }\end{array}$ & $\begin{array}{l}\text { Systemic } \\
\text { risks }\end{array}$ \\
\hline Credit risk & $\begin{array}{l}\text { Deplaced } \\
\text { Commercial } \\
\text { risk }\end{array}$ & ALM risk & $\begin{array}{l}\text { Operational } \\
\text { risk }\end{array}$ & $\begin{array}{l}\text { Business } \\
\text { Environment } \\
\text { risk }\end{array}$ \\
\hline $\begin{array}{l}\text { Market risk } \\
\text {-Mark-up risk }\end{array}$ & $\begin{array}{l}\text { Withdrawal } \\
\text { risk }\end{array}$ & $\begin{array}{l}\text { Liquidity } \\
\text { risk }\end{array}$ & Fiduciary risk & $\begin{array}{l}\text { Institutional } \\
\text { risk }\end{array}$ \\
\cline { 2 - 5 } exchange risk & $\begin{array}{l}\text { Solvency } \\
\text { risk }\end{array}$ & $\begin{array}{l}\text { Hedging } \\
\text { risk }\end{array}$ & $\begin{array}{l}\text { Transparency } \\
\text { risk }\end{array}$ & $\begin{array}{l}\text { Regulatory } \\
\text { risk }\end{array}$ \\
\hline
\end{tabular}

Sumber: Islamic Fnancial Institutions (IFI) dalam Saïda Daly and Mohamed Frikha (2015)

Permasalahan risiko kredit dan pembiayaan hingga saat ini menjadi momok bagi lembaga keuangan. Bahkan di provinsi Sulawesi Selatan, Otoritas Jasa Keuangan (OJK) memberikan peringatan dari akibat kondisi ekonomi yang melambat sehingga menyebabkan risiko kredit naik pada awal tahun 2016. Kenaikan rasio kredit atau non peforming loan (NPL) sebesar 14 basis points (bps) menjadi 2,87 per Februari 2016 dibandingkan periode yang sama tahun sebelumnya 2,73 $\%$, padahal pertumbuhan kredit menurun $11 \%$ sebesar 121,34 triliun per Februari 2016 dibanding posisi 137,13 triliun per Februari 2015. ${ }^{190}$

Dampak dari kenaikan NPL tersebut, OJK sendiri menutup salah satu Bank Pengkreditan Rakyat (BPR) Dana Niaga Mandiri

${ }^{189}$ Saïda Daly and Mohamed Frikha, "Variety in the Rules of Islamic Financial Institutions", Arabian Journal of Business and Management Review vol. 5. Issue 1 (2015), h. 4.

190“Kredit Bemasalah Makin Gemuk” (Berita), Tribun Timur, selasa 19 April 2016. 
(DNM) Makssar yang disebabkan bank tersebut memiliki masalah likuiditas akut yang tidak bisa dipenuhi oleh manajemen. ${ }^{191}$ Melihat fenomena di atas, Lesmana dalam Teddy Oswari mengemukakan perlu adanya independent security sebagai bentuk pengamanan bagi risiko kredit yang disalurkan perbankan dan LJKNB yaitu model manajemen risiko kredit yang spesifik. ${ }^{192}$

Mencermati berbagai keterangan dan penjelasan diatas, maka penulis bermaksud mengangkat judul "Analisis Penerapan Manajemen Risiko Pembiayaan Pada Lembaga Pembiayaan Syariah”.

\section{B. KAJIAN TEORITIS}

1. Risiko Pembiayaan dalam Islam

Risiko kredit atau risiko pembiayaan adalah risiko yang muncul akibat kegagalan debitur dan/atau pihak lain dalam memenuhi kewajiban kepada perusahaan pembiayaan. ${ }^{193}$ Dalam Islam, pinjaman dan bentuk lain dari pembayaran ditangguhkan dianggap sebagai kewajiban yang harus dipenuhi oleh peminjam tersebut. ${ }^{194}$ Kegagalan bayar (default) dari peminjam dibedakan dalam dua jenis, yaitu sebagai berikut:

a. Yang mampu bayar (gagal bayar sengaja)

b. Gagal bayar karena bangkrut, yaitu tidak mampu membayar

191 "Kredit Bemasalah Makin Gemuk" (Berita), Tribun Timur, selasa 19 April 2016.

${ }^{192}$ Teddy Oswari, "Model Antisipasif Manajemen Risiko Kredit : Variabel Kontinjensi Terhadap Sistem Manajemen Risiko", h. 1.

${ }^{193}$ Otoritas Jasa Keuangan, Peraturan Otoritas Jasa Keuangan, Nomor 1/POJK.05/ 2015 Tentang Penerapan Manejemen Risiko bagi Lembaga Jasa Keunagan Non Bank, BAB I, Pasal 1.

${ }^{194}$ Siti Khadijah Ab Manan and Muhammad Hakimi Bin Mohd Shafi ai, 'Risk Management of Islamic Microfinance (IMF) Product by Financial Institutions in Malaysia", h. 84. 
kembali utangnya karena alasan-alasan yang diakui syariah. ${ }^{195}$

Islam sangat menjunjung tinggi aspek keadilan, keadilan dalam kasus kegagalan bayar yang disengaja sangat diperhatikan dalam Islam sebagaimana dalam QS. al-Maidah/5: 1.

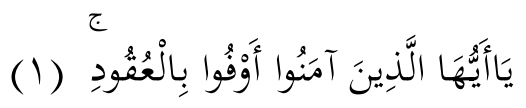

Terjemahnya:

Hai orang-orang yang beriman, penuhilah akad-akad itu. ${ }^{196}$

Akad (perjanjian) yang dimaksud ayat tersebut mencakup janji hamba kepada Allah dan Perjanjian yang dibuat oleh manusia dalam pergaulan sesamanya maka barang siapa yang melakukan perjanjian dan tidak memenuhinya maka dia dianggap berdosa. ${ }^{197}$ Menurut Yūsuf Qarḍāwi jika seseorang mengulur-ngulur pembayaran utang padahal sebenarnya ia mampu, maka ia ẓalim dan berhak mendapatkan siksaan sebagai orang-orang zalim di dunia dan akhirat. ${ }^{198}$ Hadiṣ dari Abū Hurairah:

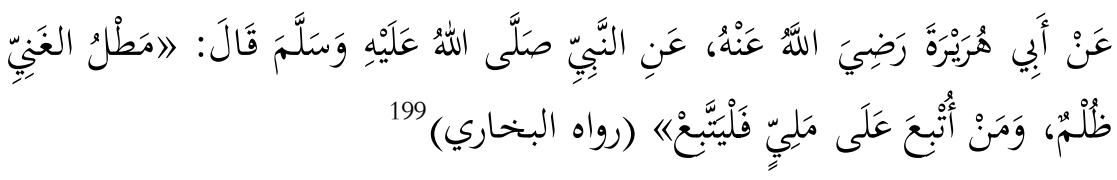

${ }^{195}$ Bambang Rianto Rustam, Manajemen Risiko Perbankan Syariah di Indonesia., h. 55.

${ }^{196}$ Kementerian Agama Republik Indonesia, Al-Qur'an dan Terjemahnya (Semarang: Asy-Sifa, 2001), h. 156.

${ }^{197}$ Siti Khadijah Ab Manan and Muhammad Hakimi Bin Mohd Shafi ai, 'Risk Management of Islamic Microfinance (IMF) Product by Financial Institutions in Malaysia", h. 84.

${ }^{198}$ Y ūsuf Qarḍ̄wi, Peran Nilai dan Moral dalam Perekonomia Islam, terj, Didin hafidhuddin, dkk., (Jakarta: Robani Press, 2001), h. 317.

${ }^{199}$ Muhammad ibn Ismā'il Abū Abdillāh al-Bukhārīi, Sahị̣ alBukharī juz 3, h. 94. 
Artinya:

Dari Abi Hurairah bahwa Rasulullah saw berkata: Penangguhan pembayaran utang oleh orang yang mampu adalah suatu kezaliman, dan barang siapa yang dialihkan kepada orang mampu maka terimalah pengalihan itu. (HR. Bukhari)

Tentang sanksi yang akan dikenakan di dunia, Nabi saw.

Bersabda:

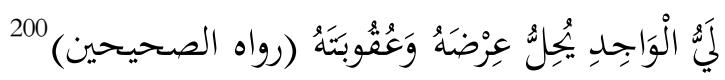

Artinya:

Mengundur-ngundur pembayaran utang bagi orang yang mampu adalah menghalalkan harga dirinya (untuk dihinakan) dan hukuman kepada-nya. ( HR. Șahịhain)

Sedangkan hukuman akhirat sungguh sangat keras karena berhubungan dengan hak-hak hamba. Sebab, masalah yang berkaitan hamba dengan sesama hamba harus diselesaikan antar mereka dan tidak bisa mengandalkan pemaafan semata-mata. Hal yang paling dikhawatirkan bagi orang yang berutang adalah jika ia meninggal dunia dengan masih menanggung utang dan tidak meninggalkan warisan yang cukup untuk melunasinya. Rasulullah mengatakan:

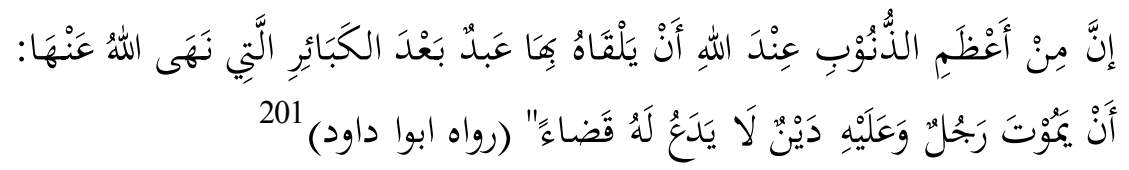

Artinya:

Seseungguhnya diantara dosa yang paling besar di sisi Allah yang dibawa seorang hamba ketika menghadap Allah setelah dosa-dosa besar yang dilarang Allah, yaitu seseorang meninggal dunia dalam keadaan masih menanggung utang sedangkan ia tidak meninggalkan sesuatu yang cukup untuk melunasinya (HR. Abū Dāud)

${ }^{200}$ Abū Abdillāh al-Hākim Muhammad ibn Abdullāh, Al-Mustadrak 'ala' al-Ṣahịhaini, juz 4 (Beirut: Dār al-Kutub al-'Ilmiyyah, 1990), h. 114.

${ }^{201}$ Abū Dāud Sulaimān ibn al-As' at, Sunan Abī Dāud al-Arnaūt, juz 5 (tt: Dār al-Risālah al-'Ilmiyah, 1430H/2009), h. 230. 
Di antara ancaman yang paling keras dalam hal ini adalah hadiṣ yang menyatakan bahwa kematian syahid di jalan Allah yang demikian tinggi derajatnya di sisi Allah tidak dapat mengugurkankan tanggungan utang dari orang yang berutang.

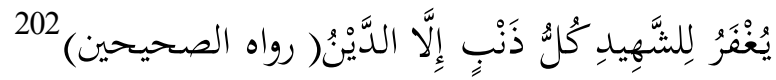

Artinya:

Diampuni bagi orang yang mati syahid setiap dosanya kecuali utang. (HR. Șaḥiḥaini).

Islam tidak hanya memberikan ancaman bagi orang yang tidak membayar utang. Akan tetapi, Islam juga membahas bagi mereka yang gagal membayar karena bangkrut. Allah meletakkan keadilan dalam bermuamalah utang-piutang, ketika pemilik uang mengalami kerugian dari peminjam yang bangkrut maka Allah memberikan keuntungan lain yaitu pahala di akhirat kelak sebagaimana dalam QS. al-Baqarah/2: 280.

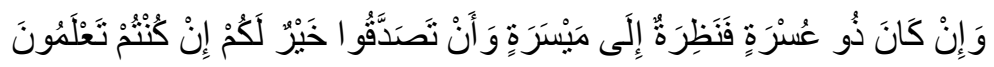

Terjemahnya:

dan jika (orang yang berhutang itu) dalam kesukaran, Maka berilah tangguh sampai Dia berkelapangan. dan menyedekahkan (sebagian atau semua utang) itu, lebih baik bagimu, jika kamu mengetahui. ${ }^{203}$

Selanjutnya ganjaran bagi mereka yang memberikan keringanan membayar utang sebagaimana disebutkan dalam hadiṣ.

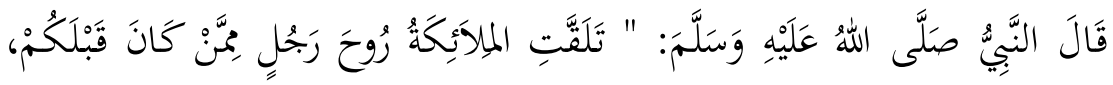

${ }^{202}$ Abū Abdillāh al-Hākim Muhammad ibn Abdullāh, Al-Mustadrak 'ala' al-Ṣahihhaini, juz 2, h. 129.

${ }^{203}$ Kementerian Agama Republik Indonesia, Al-Qur'an dan Terjemahnya, h. 70. 


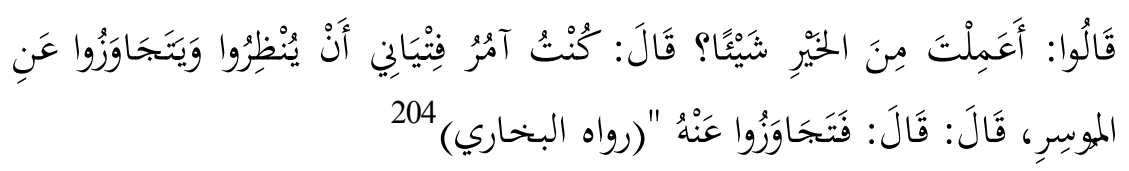

Artinya:

Nabi saw. berkata: malaikat menyambut ruh seseorang yang sebelum kami, lalu mereka berkata: apakah anda telah berbuat kebaikan? Jawab nabi: aku biasa menyuruh buruh-buruhku supaya memberi tempo pada orang yang belum dapat membayar karena belum punya, dan berlaku dan berlaku baik baik pada yang kaya (dapat membayar). Maka malaikat berkata: maka maafkanlah mereka (maka mereka memaafkannya). (HR. Bukhāri)

Kandungan hadị tersebut bahwa menggunakan utang dari orang kesulitan dan mengeluarkan kesulitan dari orang-orang yang menemukan kesulitan merupakan perbuatan yang besar pahalanya di sisi Allah dan di sisi manusia merupakan pujian dan syukur. ${ }^{205}$ b. Faktor-Faktor Penyebab Risiko Pembiayaan

Menurut Bambang Rianto bahwa pembiayaan bermasalah banyak disebabkan karena analisis pembiayaan yang keliru dan buruknya karakter nasabah. Selain itu, pembiayaan yang macet juga disebabkan oleh faktor internal bank dan nasabah. Penyebab lain muncul dari faktor eksternal, yaitu kegagalan bisnis dan ketidakmampuan manajemen. Kegagalan strategi perbankan syariah dalam pembiayaan korporasi semakin meningkatkan NPF. ${ }^{206}$ Selanjutnya Bambang Rianto menambahkan penyebab pembiayaan bermasalah dari aspek risiko operasional sebagai berikut:

${ }^{204}$ Muhammad ibn Ismā'il Abū Abdillāh al-Bukhārī, Sahịh alBukharī, juz 3. h. 57.

${ }^{205}$ Ayat Dimyati, Hadist Arba'in Masalah aqidah, Syariah, \& Akhlaq (Bandung: Penerbit Marja, 2001), h. 124.

${ }^{206}$ Bambang Rianto Rustam, Manajemen Risiko Perbankan Syariah di Indonesia., h. 58. 
Tabel 2.

Penyebab Pembiayaan Bermasalah dari Aspek Risiko Operasional

\begin{tabular}{|c|c|}
\hline Tahapan & Proses Salah \\
\hline $\begin{array}{l}\text { 1. Aplikasi } \\
\text { Pembiayaan }\end{array}$ & $\begin{array}{l}\text { Kurangnya verifikasi keaslian dan sah } \\
\text { tidaknya permohonan pembiayaan }\end{array}$ \\
\hline $\begin{array}{l}\text { 2. Analisis } \\
\text { Pembiayaan }\end{array}$ & $\begin{array}{l}\text { a. Analisis awal kurang tajam } \\
\text { b. Kebenaran informasi dan data } \\
\text { kurang terverifikasi } \\
\text { c. Asumsi dasar yang digunakan } \\
\text { jauh meleset } \\
\text { d. Analisis kuantitatif dan } \\
\text { kuantitatif tidak tepat } \\
\text { e. Analisis dangkal dan alat analisis } \\
\text { tidak cukup }\end{array}$ \\
\hline $\begin{array}{l}\text { 3. Pencairan } \\
\text { Pembiayaan }\end{array}$ & $\begin{array}{l}\text { a. Dokumentasi pembiayaan cacat } \\
\text { hukum } \\
\text { b. Pencairan tanpa persetujuan } \\
\text { otoritas }\end{array}$ \\
\hline $\begin{array}{l}\text { 4. Pemantauan } \\
\text { Pembiayaan }\end{array}$ & $\begin{array}{l}\text { a. Covenant pembiayaan tidak } \\
\text { dipantau baik } \\
\text { b. Jaminan belum diasuransikan } \\
\text { c. Kunjungan rutin tidak dilakukan }\end{array}$ \\
\hline
\end{tabular}

Sumber: Bambang Rianto (2013)

Sedangkan dari hasil penelitian Edwin dan Williasih mengatakan moral hazard biasa terjadi pada pembiayaan bagi hasil karena ketidaksempurnaan informasi petugas melihat level usaha nasabah dan terbatasnya informasi produktivitas usaha. Sementara itu, pada pembiayaan murabahah tingginya NPF terjadi karena kesalahan bank melakukan assessment debitur dan kurangnya monitoring (pengawasan/ pemantauan) nasabah. ${ }^{207}$

${ }^{207}$ Mustafa Edwin dan Ranti Williasih, "Profit Sharing dan Moral hazard dalam Penyaluran Dana Pihak Ketiga Indonesia" Jurnal Ekonomi dan Pembangunan Indonesia. Vol IIV. No. II. (2007), h. 125. http://staff.ui.ac.id/system/files/users/mustafa.nasution/publication/bf - 
Selanjutnya sebagai perbandingan, Teguh Pudjo Muljono dalam Bambang Rianto memberikan dua sebab terjadinya kredit gagal sebagai berikut:

\section{1) Faktor Internal}

a) Adanya self dealing atau tindak kecurangan dari aparat pengelola kredit.

b) Minimnya pengetahuan/keterampilan para pengelola kredit.

c) Kurang baiknya manajemen sistem informasi yang dibangun.

d) Lemahnya organisasi dan manajemen.

e) Tidak adanya kebijakan prekreditan yang baik.

f) Adanya sikap yang ceroboh, lalai, dan mengampangkan dari pengelola perkreditan.

2) Faktor Eksternal

a) Kegiatan prekonomian makro/kegiatan/politik/

b) kebijaksanaan pemerintah yang diluar jangkauan perusahaan untuk diperkirakan.

c) Adanya bencana alam dan kejadian lain diluar dugaan.

d) Adanya persaingan bisnis kredit sehingga perusahaan tidak mampu melakukan seleksi risiko usahanya. ${ }^{208}$

2. Manajemen Risiko Lembaga Keuangan

Pengertian manajemen risiko merupakan bagian integral dari proses manajemen yang berjalan dalam perusahaan atau lembaga suatu usaha untuk mengetahui, menganalisis serta mengendalikan risiko dalam setiap kegiatan perusahaan dengan tujuan untuk memperoleh

b 1 c 43 profit sharing dan moral. mustafa e nasution ok.pdf (diakses pada tanggal 24 Oktober 2016)

${ }^{208}$ Teguh Pudjo Muljono, Manajemen Perkreditan bagi Bank Komersial (Yogyakarta: BPFE, 2001) dalam Bambang Rianto Rustam, Manajemen Risiko Perbankan Syariah di Indonesia., h. 60. 
efektifitas dan efisiensi yang lebih tinggi. ${ }^{209}$ Menurut Zainul Arifin, Manajemen risiko adalah pengambilan risiko yang rasional dalam keseluruhan proses penanggulangan risiko termasuk risk asessement, sebagaimana tindakan-tindakan untuk membangun dan menerapkan pilihan-pilihan dan kontrol risiko. ${ }^{210}$ Ferry N. Idroes mengemukakan manajemen resiko merupakan metode logis dan sistematik dalam identifikasi, kuantifikasi, menentukan sikap, menetapkan solusi, serta melakukan monitor dan pelaporan resiko yang berlangsung pada setiap aktifitas atau proses. $^{211}$

Penerapan manajemen risiko dapat meningkatkan shareholder value, serta meningkatkan metode dan proses pengambilan keputusan yang sistematis yang didasarkan atas ketersediaan informasi. Selain digunakan untuk menilai risiko yang melekat pada instrumen atau kegiatan usaha yang relatif kompleks, juga menciptakan insfrastruktur menajemen risiko yang kokoh dalam rangka meningkatkan daya saing. ${ }^{212}$ Proses manajemen risiko dapat dijelaskan dalam gambar berikut. $^{213}$

${ }^{209}$ Soehatman Ramli, Pedoman Praktis Manajemen Risiko (Jakarta: PT. Dian Rakyat, 2010), h.16

${ }^{210}$ Zainul Arifin, Dasar-Dasar Manajemn Bank Syariah (Jakarta: Pustaka Alfabet, 2005), h.252.

${ }^{211}$ Ferry N. Idroes, Manajemen Risiko Perbankan (Jakarta: Rajawali Pers, 2008), h. 5.

${ }^{212}$ Veithzal Rivai dan Andria Permata Veithzal, Islamic Financial Management (Teori, Konsep, dan Aplikasi Lembaga Keuangan, Nasabah, Praktisi, dan Mahasiswa), h. 623.

${ }^{213}$ Bambang Rianto Rustam, Manajemen Risiko Perbankan Syariah di Indonesia., h. 43. 
Gambar 1. Proses Manajemen Risiko

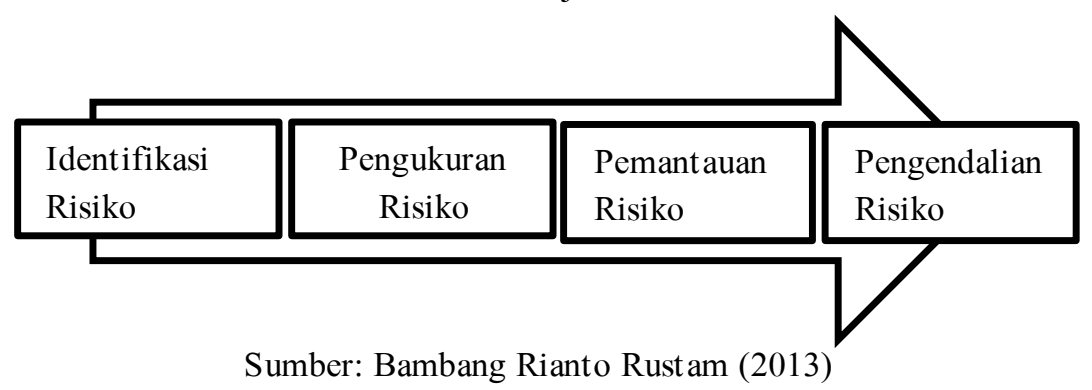

a. Identifikasi Risiko

Untuk dapat menerapkan proses manajemen risiko, maka pada tahap awal harus secara tepat mengidentifikasikan risiko dengan cara mengenal dan memahami seluruh risiko yang sudah ada (inherent risks) maupun yang mungkin timbul dari suatu bisnis baru, termasuk risiko yang bersumber dari perusahaan terkait dan afiliasi lainnya. ${ }^{214}$ Pelaksanaan proses analisis identifikasi risiko paling tidak terhadap karakteristik risiko yang melekat pada perusahaan yang didasarkan pada pengalaman kerugian perusahaan yang pernah terjadi. ${ }^{215}$

b. Pengukuran Risiko

Setelah dilakukan identifikasi risiko secara akurat, selanjutnya melakukan pengukuran risiko. Pengukuran risiko tersebut dengan maksud agar mampu mengalkulasi eksposur risiko yang melekat pada kegiatan usahanya sehingga dapat memperkirakan dampaknya

${ }^{214}$ Veithzal Rivai dan Andria Permata Veithzal, Islamic Financial Management (Teori, Konsep, dan Aplikasi Lembaga Keuangan, Nasabah, Praktisi, dan Mahasiswa), h. 622. Lihat juga Veitzhal Rivai, dkk. Bank and Financial Institution Management: Conventional and Syar'I System (Jakarta:RajaGrafindo Persada, 2007), h. 792.

${ }^{215}$ Bambang Rianto Rustam, Manajemen Risiko Perbankan Syariah di Indonesia., h. 44. 
terhadap permodalan yang seharusnya dipelihara dalam rangka mendukung kegiatan usaha. Pengukuran dan kuantifikasi risiko akan sangat bergantung dari karakteristik risiko tersebut. ${ }^{216}$ Tabel berikut ini menyajikan ringkasan tipe-tipe risiko dan teknik pengukurannya yang berbeda-beda.

Tabel 3. Pengukuran untuk Beberapa Risiko

\begin{tabular}{|l|l|l|}
\hline Tipe Risiko & \multicolumn{1}{|c|}{ Definisi } & Teknik Pengukuran \\
\hline Risiko Pasar & $\begin{array}{l}\text { Harga pasar bergerak ke } \\
\text { arah yang tidak } \\
\text { menguntungkan } \\
\text { (merugikan) }\end{array}$ & $\begin{array}{l}\text { Value at Risk } \\
\text { (VAR), Stress- } \\
\text { testing }\end{array}$ \\
\hline $\begin{array}{l}\text { Risiko } \\
\text { Kredit }\end{array}$ & $\begin{array}{l}\text { Counterparty tidak bisa } \\
\text { membayar kewajibannya } \\
\text { (gagal bayar) ke } \\
\text { perusahaan }\end{array}$ & $\begin{array}{l}\text { Credit rating, } \\
\text { Creditmetrics, } \\
\text { CreditRisk+, KMV } \\
\text { dan lain-lain. }\end{array}$ \\
\hline $\begin{array}{l}\text { Risiko } \\
\text { perubahan } \\
\text { tingkat } \\
\text { bunga }\end{array}$ & $\begin{array}{l}\text { Tingkat bunga berubah } \\
\text { yang mengakibatkan } \\
\text { kerugian pada portfolio } \\
\text { perusahaan }\end{array}$ & $\begin{array}{l}\text { Metode } \\
\text { pengukuran jangka } \\
\text { waktu, durasi }\end{array}$ \\
\hline $\begin{array}{l}\text { Risiko } \\
\text { operasional }\end{array}$ & $\begin{array}{l}\text { Kerugian yang terjadi } \\
\text { melalui operasi } \\
\text { perusahaan (misal sistem } \\
\text { yang gagal) }\end{array}$ & $\begin{array}{l}\text { Matriks frekuensi } \\
\text { dan signifikasi } \\
\text { kerugian, VAR } \\
\text { operasional }\end{array}$ \\
\hline $\begin{array}{l}\text { Risiko } \\
\text { kematian }\end{array}$ & $\begin{array}{l}\text { Manusia mengalami } \\
\text { kematian dini (lebih } \\
\text { cepat dari usia kematian } \\
\text { wajar) }\end{array}$ & $\begin{array}{l}\text { Probabilitas } \\
\text { kematian dengan } \\
\text { tabel mortalitas }\end{array}$ \\
\hline $\begin{array}{l}\text { Manusia terkena terkena } \\
\text { penyakit tertentu }\end{array}$ & $\begin{array}{l}\text { Probabilitas } \\
\text { terkena penyakit } \\
\text { kengan }\end{array}$ \\
\hline
\end{tabular}

${ }^{216}$ Mamduh H. Hanafi, Manajemen Risiko, h. 57. 


\begin{tabular}{|l|l|l|}
\hline & & $\begin{array}{l}\text { menggunakan tabel } \\
\text { morbiditas }\end{array}$ \\
\hline $\begin{array}{l}\text { Risiko } \\
\text { teknologi }\end{array}$ & $\begin{array}{l}\text { Perubahan teknologi } \\
\text { mempunyai konskuensi } \\
\text { negatif terhadap } \\
\text { perusahaan }\end{array}$ & Analisis skenario \\
\hline
\end{tabular}

Sumber: Mamduh M. Hanafi (2014)

\section{c. Pemantauan Risiko}

Sementara itu, dalam rangka melaksanakan pemantauan risiko, harus melakukan evaluasi terhadap eksposur risiko, terutama yang bersifat material dan atau yang berdampak pada permodalan. Hasil pemantauan yang mencakup evaluasi terhadap eksposur risiko tersebut dilaporkan secara tepat waktu, akurat dan informasi yang akan digunakan oleh pihak pengambil keputusan, termasuk tindak lanjut yang diperlukan. ${ }^{217}$

d. Pengendalian Risiko

Selanjutnya berdasarkan hasil pemantauan tersebut, melakukan pengendalian risiko yang memadai dengan mengacu pada kebijakan dan prosedur yang telah ditetapkan. ${ }^{218}$ Pengendalian risiko dapat dilakukan, antara lain dengan cara hedging dan metode mitigari risiko lain seperti penerbitan garansi, sekuritisasi aset, dan credit derivatives, serta penambahan modal untuk menyerap potensi

${ }^{217}$ Veithzal Rivai dan Andria Permata Veithzal, Islamic Financial Management (Teori, Konsep, dan Aplikasi Lembaga Keuangan, Nasabah, Praktisi, dan Mahasiswa), h. 629.

${ }^{218}$ Bambang Rianto Rustam, Manajemen Risiko Perbankan Syariah di Indonesia., h. 47. 
kerugian. ${ }^{219}$

3. Tinjauan Umum tentang Lembaga Pembiayan

a. Lembaga Pembiayaan

Berdasarkan Peraturan Presiden Nomor 9 Tahun 2009 tentang Lembaga Pembiayaan, lembaga pembiayaan adalah badan usaha yang melakukan kegiatan pembiayaan dalam bentuk penyediaan dana atau barang modal. Sedangkan perusahaan pembiayaan adalah badan usaha yang khusus didirikan untuk melakukan sewa guna usaha, anjak piutang, pembiayaan Konsumen, dan/atau usaha kartu kredit. ${ }^{220}$ Menurut Dahlan Siamat lembaga pembiayaan adalah badan usaha yang dilakukan kegiatan pembiayaan dalam bentuk penyediaan dana atau modal dengan tidak menarik dana secara langsung dari masyarakat. ${ }^{221}$ Dari pengertian tersebut di atas terdapat beberapa unsur-unsur:

1) Badan usaha, yaitu perusahaan pembiayaan yang khusus didirikan untuk melakukan kegiatan yang termasuk dalam bidang usaha lembaga pembiayaan.

2) Kegiatan pembiayaan, yaitu melakukan kegiatan atau aktivitas dengan cara membiayai pada pihak-pihak atau sektor usaha yang membutuhkan.

3) Penyediaan dana, yaitu perbuatan menyediakan dana untuk suatu

${ }^{219}$ Veithzal Rivai dan Andria Permata Veithzal, Islamic Financial Management (Teori, Konsep, dan Aplikasi Lembaga Keuangan, Nasabah, Praktisi, dan Mahasiswa), h. 630.

${ }^{220}$ Republik Indonesia, Peraturan Presiden Republik Indonesia Nomor 9 Tahun 2009 Tentang Lembaga Pembiayaan, Bab I, Pasal 1. https://www.minerba.esdm.go.id/library/sijh/Perpres $\% 20$ No $\% 209 \% 20$ tahun $\%$ 202009.pdf (Diakses pada tanggal 15Oktober 2016).

${ }^{221}$ Dahlan Siamat, Manajemen Lembaga Keuangan (Edisi II; Jakarta: Fakultas Ekonomi Universitas Indonesia. 2001). h. 281. 
keperluan.

4) Barang modal, yaitu barang yang dipakai untuk menghasilkan sesuatu.

5) Tidak menarik dana secara langsung.

6) Masyarakat, yaitu sejumlah orang yang hidup bersama di suatu tempat. $^{222}$

Perusahaan pembiayaan syariah adalah perusahaan pembiayaan yang seluruh kegiatan usahanya melakukan pembiayaan syariah. Pembiayaan syariah yang dimaksud adalah penyaluran pembiayaan dengan prinsip syariah, yang artinya ketentuan hukum Islam berdasarkan fatwa dan/atau pernyataan kesesuaian syariah dari Dewan Syariah Nasional Majelis Ulama Indonesia. ${ }^{223}$

b. Pembiayaan

Istilah pembiayaan sangat melekat di lembaga keuangan syariah, karena penggunaan kata pinjaman (kredit) tidak sesuai digunakan, mengingat dalam Islam kegiatan pinjam-meminjam merupakan akad sosial bukan akad komersial. Artinya, bila seseorang meminjam sesuatu, ia tidak boleh disyaratkan untuk memberikan tambahan atas pokok pinjamannya, karena hal tersebut merupakan riba. ${ }^{224}$

Pembiayaan mempunyai banyak definisi, menurut Muhammad

${ }^{222}$ Dahlan Siamat, Manajemen Lembaga Keuangan, h. 281.

${ }^{223}$ Otorit as Jasa Keuangan, Peraturan Otoritas Jasa Keuangan Nomor 28/POJK. 05/2014 Tentang Perizinan Usaha Dan Kelembagaan Perusahaan Pembiayaan, Bab I, Pasal 1.

https://www.ifsa.or.id/regulasi/download/28.perat uran-ojk-tentang-perizinanusaha-dan-kelembagaan-perusahaan-pembiayaan.pdf (Diakses pada taanggal 15 Oktober 2016).

${ }^{224}$ Muhammad Syafi'i Antonio, Bank Syariah dari Teori Ke Praktek (Jakarta : Gema Insani bekerjasama dengan Tazkia Cendikia, 2001) h. 170. 
pembiayaan secara luas berarti financing atau pembelanjaan, yaitu pendanaan yang dikeluarkan untuk mendukung investasi yang telah direncanakan baik dilakukan sendiri maupun djalankan oleh orang lain. Dalam arti sempit, pembiayaan digunakan untuk mendefiisikan pendanaan yang dilakukan oleh lembaga pembiayaan seperti bank syariah kepada nasabah. ${ }^{225}$ Muhammad Syafi'i Antonio menjelaskan bahwa pembiayaan merupakan salah satu tugas pokok bank yaitu pemberian fasilitas dana untuk memenuhi kebutuhan pihak-pihak yang merupakan deficit unit. ${ }^{226}$

C. Gambaran Umum Obyek Penelitian

1. Risiko Pembiayaan Pada PT $X Y Z$

Tabel 4.

Non Peforming Financing (NPF) PT XYZ

\begin{tabular}{|l|c|c|c|}
\hline Bulan & 2014 & 2015 & 2016 \\
\hline Januari & $7 \%$ & $13 \%$ & $23 \%$ \\
\hline Februari & $7 \%$ & $14 \%$ & $25 \%$ \\
\hline Maret & $8 \%$ & $14 \%$ & $26 \%$ \\
\hline April & $7 \%$ & $15 \%$ & $32 \%$ \\
\hline Mei & $5 \%$ & $16 \%$ & $28 \%$ \\
\hline Juni & $10 \%$ & $16 \%$ & $29 \%$ \\
\hline Juli & $7 \%$ & $18 \%$ & $31 \%$ \\
\hline Agustus & $8 \%$ & $18 \%$ & $33 \%$ \\
\hline September & $12 \%$ & $19 \%$ & $35 \%$ \\
\hline Oktober & $11 \%$ & $20 \%$ & $37 \%$ \\
\hline November & $14 \%$ & $21 \%$ & $39 \%$ \\
\hline Desember & $12 \%$ & $22 \%$ & $41 \%$ \\
\hline
\end{tabular}

${ }^{225}$ Muhammad, Manajemen Bank Syariah (Yogyakarta; Ekonisia, 2005), h. 260. h. 160 .

${ }^{226}$ Muhammad Syafi'i Antonio, Bank Syariah dari Teori Ke Praktek, 
Perkembangan NPF PT XYZ sangat buruk. Situasi ini jelas disebabkan oleh banyaknya piutang yang tak tertagih. Penyebab NPF membesar pada PT XYZ dikarenakan kebijakan dari regulator yaitu OJK dan dewan direksi pada tahun 2014 untuk melakukan stop selling pada pembiayaan untuk produk baru, sehingga jumlah pembiayaan terus menurun dan tidak diimbangi dengan penurunan pembiayaan yang macet. Nilai NPF yang sangat besar diakui oleh pihak perusahaan mengenai kesalahan dimasa lalu tentang pengelolaan risiko yang belum dilaksanakan secara baik dan benar.

\section{Penerapan Manajemen Risiko Pembiayaan PT XYZ}

Lingkungan internal memengaruhi bagaimana strategi dan tujuan ditentukan, kegiatan bisnis disusun, risiko-risiko diidentifikasi, dan diperkirakan. Lingkungan internal juga memengaruhi desain dan menjalankan aktivitas-aktivitas kontrol, sistem informasi dan komunikasi, dan pengawasan aktivitas. Untuk memahami obyek penelitian lebih mendalam maka perlu diketahui bagaimana perusahaan memiliki filosofi manajemen risiko. Filosofi manajemen risiko yang dipahami oleh seluruh personil akan mempermudah pengenalan kemampuan karyawan dan mengelola risiko secara efektif. Filosofi tersebut merupakan kepercayaan dan perilaku bersama dalam perusahaan tentang bagaimana mempertimbangkan risiko dipilih untuk mengontrol aktivitas-aktivitas yang ada dan menangani risiko. Untuk mengetahui filosofi perusahaan biasanya jajaran direktur atau kepala cabang menyampaikan filosofi tersebut pada karyawan melalui pernyataan-pernyataan kebijakan dan penyampaian lainnya ketika melakukan rapat, meeting, dan breafing. Paling utama, jajaran direktur menanamkan filosofi tersebut bukan hanya dengan kata-kata, namun 
juga dengan tindakan nyata tiap harinya. W sering mengingat perkataan kepala cabang kepada karyawannya:

"ingat janji karyawan yang sering kita baca saat kita breafing pertama selalu berpedoman pada visi misi dan nilai perusahaan, kedua mematuhi peraturan dan SOP peruashaan, ketiga fokus pada program kerja untuk meningkat laba perusahaan, keempat selalu berpedoman pada prinsip-prinsip GCG, kelima lebih mementingkan kepentingan perusahaan daripada kepentingan individu dan golongan

Filosofi manajemen risiko akan membentuk budaya risiko

diperusahaan. Secara sederhana dapat dikatakan bahwa sasaran dari pengembangan budaya risiko dalam setiap pengambilan keputusan, baik keputusan strategis hingga keputusan yang sederhana dalam operasi sehari-hari, turut dipengaruhi potensi risiko yang ada saat ini maupun dimasa yang akan datang. Dengan demikian setiap keputusan akan diambil dengan hati-hati dan penuh pertimbangan (informed decfision making). Perilaku hati-hati dan tidak ceroboh serta penuh pertimbangan atas informasi yang ada inilah yang menjadi tujuan terciptanya budaya (sadar) risiko. Budaya sadar risiko pada PT XYZ sudah dimulai dibangun pada tingkatan kantor-kantor cabang, upaya untuk mengurangi moral hazard pada karyawan dilakukan dengan pemberian kusioner terhadap karyawan di kantor cabang. W Mengatakan:

"sekarang ini diperusahaan, dibagikan kusioner pertanyaan ke semua karyawan. Isi pertanyaannya tentang perilakunya teman-teman karyawanta, seperti apakah kamu mendapatkan teman yang berbuat kecurangan macam begitu. Jadi setiap karyawan menjadi mata-mata bagi temannya yang lain. Kalau ada kedapatan maka dikasi sanksi" "228

${ }^{227}$ W , Kepala Administrasi PT XYZ, Wawancara, Makassar, 21 April 2017.

${ }^{228} \mathrm{~W}$, Kepala Administrasi PT XYZ, Wawancara, Makassar, 21 April 2017. 
Hal yang dilakukan PT XYZ baru dimulai bulan Maret, sesuai dengan pendapat Irhan Fahmi bahwa untuk mengurangi tingkat kecurangan pada karyawan perlu dilakukan pencegahan salah satunya ialah memberikan sanksi yang tegas kepada mereka yang melakukan kecurangan dan memberikan penghargaan kepada mereka yang berprestasi. ${ }^{229}$ Maka pola yang dilakukan dengan memberikan kusioner atau mewancarai karyawan yang melakukan kecurangan.

Proses pembentukan budaya risiko tidak hanya dengan pembentukan karakter pada individu saja, akan tetapi perusahaan juga mempunyai peran yang yang sama. Untuk itu pola perubahan budaya risiko akan maksimal dengan metode top down yang berarti dimulai dari jajaran direktur hingga karyawan. Proses ini juga berasaskan pada filosofi manajemen risiko diawal ketika perilaku kepala cabang memberikan pengaruh terhadap karyawannya.

Upaya yang dilakukan oleh PT XYZ untuk mensosiolisasikan bahaya risiko dengan mengadakan pelatihan-pelatihan serta rapat evaluasi setiap bagian. Sosialisasi dan pelatihan yang ekstensif ini bertujuan memberi pengetahuan ke seluruh karyawan menjadi tahu apa itu risiko dan sadar apa artinya manajemen risiko dalam kegiatan operasional perusahaan dan akhirnya melalui pelatihan yang tepat mereka menjadi mampu dalam menerapkan manajemen risiko tersebut. 230 Menurut saudari S mengatakan: "bagian risk management dari pusat biasanya datang sebulan sekali untuk sosiolisasi, ikutmi juga

${ }^{229}$ Irfan Fahmi, Manajemen Risiko Teori, Kasus dan Solusi (Bandung: Penerbit Alfabeta, 2016), h, 171.

${ }^{230}$ Komite Nasional Kebijakan Governance, Pedoman Penerapan Manajemen Risiko Berbasis Governance, (Jakarta: KKNG, 2012), h. 75. http://www.knkg-indonesia.org/dokumen/Pedoman-Manajemen-RisikoBerbasis-GCG.pdf (diakses pada tanggal 15 Mei 2017). 
kusionernya yang dibagikan pada karyawan" 231

Tentunya, sosiolisasi ini dilakukan sebulan sekali dengan pengontrolan setiap hari. Unsur terpenting dalam mendukung terciptanya budaya risiko adalah insentif dan sanksi. Ini adalah upaya untuk merangsang, mendorong dan mendukung perilaku budaya risiko yang diinginkan dan mencegah serta mempersulit perilaku budaya risiko yang tidak diinginkan. Untuk itu perlu penyelarasan antara pencapaian sasaran perusahaan dengan perilaku yang diinginkan, karena perilaku inilah yang layak untuk mendapatkan insentif.

Risk Appetite merupakan komponen lingkungan internal yang ada pada jajaran direktur. Perusahaan mendefinisikan risk appetite sebagai tingkat dan jenis risiko yang bersedia diambil oleh perusahaan dalam rangka mencapai sasaran bisnis perusahaan. Risk appetite yang ditetapkan oleh perusahaan tercermin dalam strategi dan sasaran bisnis perusahaan. Saat ini PT XYZ siap menerima penurunan pembiayaan dan fokus terhadap penarikan utang nasabah, untuk mengembalikan kepercayaan publik terhadap perusahaan dan juga mencapai visi misi perusahaan. Sebagaimana yang dikatakan oleh Bapak A:

"kondisi pasar sekarang tidak bagus, lalu perusahaan juga fokus terhadap penarikan utang nasabah, jadi untuk saat ini kita tidak memikirkan profit dulu walaupun perusahaan ini berorentasi pada profit. Perusahaan mengikuti dan patuh dengan regulator (OJK) maksudnya untuk mencapai perusahaan pembiayaan yang terbaik harus mempunyai integritas tinggi terhadap risiko"

Risk Appetite yang dikemukakan oleh bapak A menunujukkan adanya penyesuaian antara kondisi risiko pembiayaan dengan

\footnotetext{
${ }^{231}$ Saudari S, Kasir PT XYZ, Wawancara, Makassar, 24 April 2017.

${ }^{232}$ Bapak A, Kepala Cabang PT XYZ, Wawancara, Makassar, 19
} April 2017. 
keuntungan yang ingin dicapai pada perusahaan. penyesuaian antara risiko dan keuntungan ini diaplikasikan dengan kondisi pasar penjualan yang kurang baik sehingga tidak memungkinkan untuk mencapai target yang tinggi dalam menjual lalu memfokuskan kepada penarikan pembiayaan yang macet. Hal ini sesuai dalam pendapat James Law bahwa ketika perusahaan yang mengalami excessise risk taking akan berdampak buruk apabila mengambil lebih banyak lagi risiko, dan kalau diilustrasikan dalam pembiayaan bisa dikatakan melakukan ekspansi penjualan akan berdampak buruk terhadap risiko pembiayaan kedepannya. ${ }^{233}$

Budaya risiko akan menghasilkan integritas dan nilai moral di lingkungan perusahaan. Hal ini bisa dimulai dari kepala cabang dalam berperilaku, lalu disertai oleh bawahan. PT XYZ melakukan pengidentifikasian dengan kusioner untuk menilai nilai moral dan integritas karyawan, hasil kusioner tersebut dikatakan oleh $\mathrm{W}$ "selama ini, setelah penyebaran kusioner belumpi didapat kecurangan di antara karyawan, dan semoga tidak terjadi hal demikian". ${ }^{234}$ Berdasarkan wawancara tersebut karyawan sudah mempunyai integritas untuk mengelola risiko, integritas ini juga saling berhubungan dengan nilai moral dimana kedua komponen ini perlu diberikan siraman rohani. PT XYZ kadang melakukan acara pengajian dengan memanggil ustads sebagai narasumber, agar supaya nilai-nilai keislaman dalam diri tidak luntur. Dengan begitu proses kerja dengan nilai-nilai perusahaan bisa tercapai dengan integritas dan nilai moral control, h. 5.

${ }^{233}$ James Law, Enterprise Risk Management from Incentives to

${ }^{234}$ Saudara W , Kepala Administrasi PT XYZ, Wawancara, Makassar, 21 April 2017. 
pada karyawan.

Struktur Organisasi PT XYZ pada Gambar 2 dapat dianalisis secara mendalam mengenai pola pengelolaan manajemen risiko secara struktural. Dapat dilihat bahwa penempatan risk management langsung mengarah kepada divisi surveyor dan collection.

Gambar 2. Struktur Organisasi PT XYZ

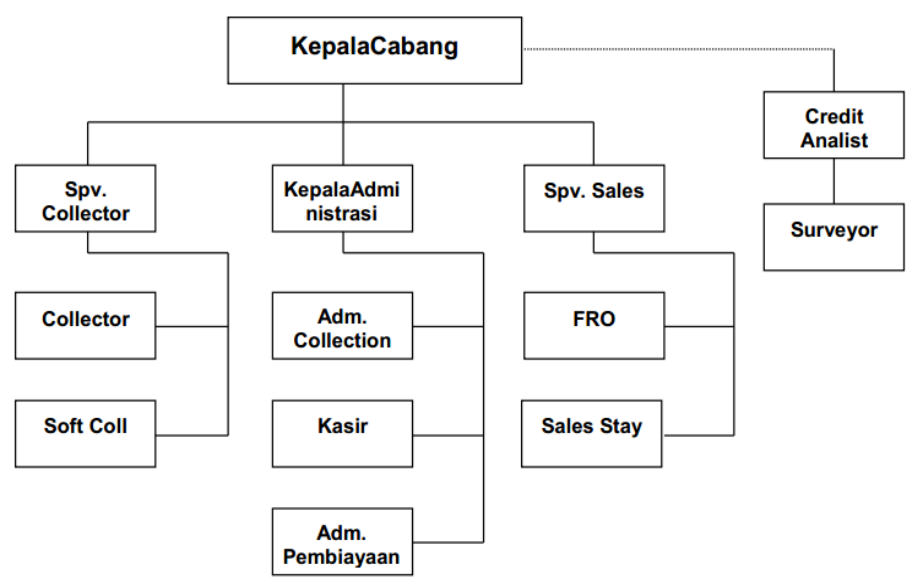

Sumber: PT XYZ 2017

Hal ini jelas bahwa PT XYZ memerhatikan risiko pembiayaan sebagai risiko utama dalam perusahaannya sebagaimana yang dikatakan oleh Bapak A:

"risiko yang kita utamakan jelas tunggakan macet, maka divisi risk management mengontrol langsung terhadap kolektor dan surveyor supaya tidak terjadi hal yang merugikan perusahaan. saat ini, risk management seringberkunjung ke kantor cabang untuk pengontrolan" 235

Selain itu, pada gambar penempatan credit analist sejajar

${ }^{235}$ Bapak A, Kepala Cabang PT XYZ, Wawancara, Makassar, 19 April 2017. 
dengan kepala cabang. Fungsi penempatan itu dilakukan sebagai salah satu penentu kebijakan dalam rapat credit comitte pada saat keputusan diterimanya suatu pembiayaan. Kadang kala kepala cabang tidak memerhatikan lima $\mathrm{C}$ dalam persetujuan pembiayaan nasabah, maka dari itu konsep sturuktural itu dibuat sejajar antara kepala cabang dan credit analist sebagaimana dikatakan oleh Sugianti bahwa "credit analist itu dari orang pusat, sebagai mata-mata di kantor cabang. Supaya aktivitas piutang usaha terkontrol". ${ }^{236}$

Sebagaimana dikemukakan oleh Stoner, dkk., dalam Ernie Isnawati, ada empat pilar (building blocks) yang menjadi dasar untuk melakukan proses pengorganisasian, keempat pilar tersebut adalah pembagian kerja (division of work), pengelompokan pekerjaan (departmentalization), penentuan relasi antarbagian dalam organisasi (hierarchy), Serta penentuan mekanisme untuk mengintegrasikan aktivitas antar bagian dalam organisasi atau koordinasi (coordination). ${ }^{237}$

Pembagian kerja yang efektif tergantung pada kompetensi karyawan. Kompetensi dalam perspektif Enterprise Risk Management ialah pengetahuan dan keterampilan seseorang yang dibutuhkan perusahaan dalam mengerjakan tugasnya. Manajemen menentukan tingkat kompetensi dan memutuskan syarat untuk menjadi karyawan diperusahaan. $^{238}$ Perekrutan calon karyawan yang berkualitas merupakan tonggak awal terciptanya kompetensi. Sistem kontrak bagi

${ }^{236}$ Sugianti, Kasir PT XYZ, Wawancara, Makassar, 24 April 2017.

${ }^{237}$ Ernie Tisnawati Sule \& Kurniawan Saefullah, Pengantar Manajemen. h. 153.

${ }^{238}$ Committee of Sponsoring Organzations (COSO) of the Treadway Commision,. Enterprise Risk Management-Integrated Framework (Executive Summary), h, 31 . 
karyawan baru yang diterapkan oleh perusahaan merupakan salah satu usaha manajemen mendorong terciptanya SDM yang baik yang bertujuan meningkatkan kinerja perusahaan. Karyawan yang mempunyai kompotensi di bidangnya merupakan syarat mutlak untuk mengelola risiko pada perusahaan. Karyawan yang kompoten membidangi pengelolaan piutang usaha pada PT XYZ dapat dilihat dari kebijakan manajemen, yaitu berupa :

1) prosedur perekrutan calon karyawan dengan selektif melalui tahap-tahap seleksi sesuai dengan bidangnya masing-masing yakni minimal kelulusan diploma bidang ekonomi akuntansi dengan standar IPK 3.00 dan berasal dari perguruan tinggi terakreditasi bagi staff front liner dan minimal S1 bidang ekonomi akuntansi bagi staff back office,

2) pemberlakuan kontrak kerja bagi karyawan baru dengan tiga alternatif pertimbangan, yakni alternatif pertama apabila performance karyawan tersebut di atas rata-rata dan telah habis masa kontraknya maka akan diangkat menjadi karyawan tetap, alternatif kedua adalah apabila performance karyawan tersebut dibawah rata-rata tapi tidak buruk, maka kontaknya diperpanjang sampai waktu yang telah ditentukan, alternatif ketiga adalah apabila performance karyawan tersebut buruk, maka kontrak diputus. Performance karyawan perusahaan diukur melalui penilaian karyawan setiap tiga bulan oleh seccion head masing-masing dan laporan auditor internal mengenai prosedur kerja yang telah dijalankan setiap karyawan.

Untuk menjadikan perusahaan tetap dalam kinerja yang bagus maka aktivitas pengontolan merupakan unsur penting dalam mangeatur manajemen risiko. aktivitas pengontrolan PT XYZ berupa 
breafing yang diikuti oleh setiap personil yang dikepalai oleh Kepala Cabang, dalam kegiatan tersebut, seccion head memberikan informasi akhir mengenai hasil pencapaian, sehingga akan diketahui kinerja per bagian atau divisi, disamping itu setiap personil berhak memberikan tanggapan, saran, atau masukan ke arah perbaikan, sedangkan kepala cabang bertugas untuk mengkoordinasikan dan memberikan bimbingan untuk tiap-tiap bagian untuk terus meningkatkan performance. W mengatakan:

"misalnya dalam hal banyaknya konsumen yang menunggak, maka epala cabang memerintahkan agar penagihan dilakukan oleh kolektor ke rumah konsumen jika memungkinkan hingga pukul sembilan malam, disamping itu seleksi yang lebih ketat untuk calon nasabah dengan cara penambahan DP (down payment) yang lebih besar, atau syarat pekerjaan calon nasabah pegawai tetap.'

Aktivitas pengontrolan pada PT XYZ dapat dibagi ke dalam beberapa aktivitas.

a. Aktivitas pengontrolan dalam persetujuan kredit dilakukan oleh credit analyst, sedangkan otoritas perset ujuan kredit dilakukan oleh kepala cabang.

b. Aktivitis tanggungjawab dan kewenangan terhadap mutasi piutang usaha dilakukan oleh setiap personil yang berhubungan dengan piutang usaha, diantaranya tanggungjawab FRO memperoleh debitur dalam menambah piutang usaha, tanggungjawab kasir dalam menerima cash sebagai bukti pengurangan piutang usaha, serta wewenang credit analyst dan collection head dalam memimpin bawahannya dalam meningkatkan kinerja operasi untuk mendapat profitability.

${ }^{239}$ Saudara W, Kepala Administrasi PT XYZ, Wawancara, Makassar, 21 April 2017. 
c. Aktivitas pemisahan tugas oleh masing-masing bagian atau fungsi yang berhubungan dengan piutang usaha, antara lain bagian penerimaan terpisah dengan bagian pencatatan, bagian penagihan terpisah dengan bagian pencatatan, bagian penerimaan calon debitur terpisah dengan bagian piutang. Hal ini bertujuan untuk mengurangi terjadinya penyimpangan, baik penyimpangan berupa kesalahan maupun penyimpangan, baik penyimpangan berbentuk kecurangan atau penggelapan uang atau cash perusahaan. ${ }^{240}$

\section{7) Penagihan Piutang PT XYZ}

Pemantauan terhadap kelancaran piutang usaha menjadi tanggung jawab collection head. Performance setiap personil selalu dipantau berdasarkan informasi dari Report Aging Schedule periode sebelumnya, sehingga dari hasil pencapaian terhadap pengumpulan piutang usaha dilakukanlah evaluasi dan tindak lanjut. Jajaran cabang melakukan pelatihan harian setiap pagi untuk mengetahui rencana penanganan dan target penagihan. Untuk kelompok kolektor diberikan target sebagai berikut:

b. Klasifikasi lancar kolektibiltas (A): ditargetkan 100\% kreditur yang lancar.

c. Klasifikasi perhatian khusus, kurang lancar, diragukan (kolektibilitas B-D): target capaian penyetoran $80 \%$ dan minimalkan $10 \%$ penarikan unit.

d. Klasifikasi macet (kolektabilitas E-F): target capaiaan untuk kredit macet penarikan unit 90\%. untuk mencapai parameter ini XYZ membentuk tim khusus penyelesaian pembiayaan macet.

Setelah dilakukan meeting untuk melakukan penagihan maka

${ }^{240}$ Hasil Observasi PT XYZ, Wawancara, Makassar, 13-29 April 2017. 
kolektor menerima daftar nasabah yang dikelola yang telah dirumuskan oleh Kepala Administrasi. kolektor menerima form LKH dan kwitansi penagihan bernomor seri yang telah tercantum nomor akad, nama pelanggan, dan jumlah tagihan berdasarkan tanggal jatuh tempo maupun sesuai rencana kunjungan, setelah itu menelepon nasabah yang jatuh tempo pada hari tersebut untuk mengingatkan serta menyampaikan jumlah kewajibannya.

Nasabah yang akan melakukan pembayaran, kolektor akan memberikan kwitansi penagihan dengan terlebih dahulu mengisi jumlah pembayaran dan ditandatangani kedua pihak. Apabila nasabah tidak memenuhi janji bayar yang termuat dalam surat pernyataan customer, collector menyampaikan surat pemberitahuan tunggakan, surat peringatan (SP) I, SP II, dan SP III yang ditandatangani kepala administrasi sesuai dengan lamanya tunggakan nasabah tersebut, disertai tanda terima yang ditanda tangani oleh nasabah. Bila dari hasil kunjungan nasabah, ternyata nasabah sudah tidak berdomisili lagi di tempat tinggal atau tempat usaha segera mencari informasi dari orang yang biasa dihubungi, baik sales dealer atau keluarga dari nasabah tersebut.

\section{8) Penanganan Nasabah Bermasalah}

Menangani nasabah bermasalah kepala administrasi menganalisa dan mengklasifikasikan nasabah tidak tertagih berdasarkan catatan tersebut, kemudian melaksanakan langkah penanganan nasabah ke departemen Account Receivable (AR) di kantor pusat. Departemen AR menganalisa pengajuan cabang kemudian membut perencanaan untuk memutuskan pembentukan tim hard collection dan cabang yang akan menangani. Setelah itu diterbitkan surat penarikan at as tim hard collection. Hard collection 
melakukan penarikan kendaraan dan langsung menyerahkan surat batas waktu penyelesaian tunggakan ke nasabah dengan jangka waktu 14 hari sejak pelaksanaan penitipan unit jaminan. Perpanjangan waktu penyelesaian dapat dilakukan dengan syarat permintaan secara tertulis dari cabang disertai pertimbangan ke departemen AR, perpanjangan waktu penyelesaian dapat diberikan maksimal 7 hari.

\section{Kesimpulan}

Penerapan manajemen risiko pembiayaan pada PT XYZ dikategorikan kurang cukup baik. hal ini dimaknai bahwa untuk menciptakan manajemen risiko pembiayaan maka perlu diterapkan suatu sistem manajemen risiko yang handal dan konsisten. Melihat dari hasil penelitian bahwa selama periode 2014 hingga 2016 mengalami kenaikan nilai NPF, sehingga mengharuskan perusahaan untuk bertindak cepat untuk memitigasi nilai rasio NPF. Maka langkah yang dilakukan oleh PT XYZ sudah tepat dalam memutuskan stop selling.

\section{Daftar Pustaka}

Bank Indonesia, Buku Laporan Perekonomian Indonesia tahun 2008, Jakarta: Direktorat Riset Ekonomi dan Kebijakan Moneter Bank Indonesia, 2008.

Ab Manan, Siti Khadijah. and Muhammad Hakimi Bin Mohd Shafi ai, 'Risk Management of Islamic Microfinance (IMF) Product by Financial Institutions in Malaysia", (Makalah yang disajikan pada International Accounting And Business Conference (IABC), Procedia Economics and Finance 31,(2015),

"Kredit Bemasalah Makin Gemuk" (Berita), Tribun Timur, selasa 19 April 2016.

Otoritas Jasa Keuangan, Peraturan Otoritas Jasa Keuangan, Nomor 1/POJK.05/2015 Tentang Penerapan Manejemen Risiko bagi Lembaga Jasa Keunagan Non Bank, BAB I, Pasal 1. 
Qarḍ̄āwi,Yūsuf. Peran Nilai dan Moral dalam Perekonomia Islam, terj, Didin hafidhuddin, dkk., Jakarta: Robani Press, 2001.

Muhammad, Abū Abdillāh al-Hākim. ibn Abdullāh, Al-Mustadrak 'ala' al-Ṣahịhaini, juz 4 Beirut: Dār al-Kutub al-'Ilmiyyah, 1990.

al-As'at. Abū Dāud Sulaimān ibn. Sunan Abīi Dāud al-Arnaūt, juz 5 tt: Dār al-Risālah al-'Ilmiyah, 1430H/2009.

Ayat Dimyati, Hadist Arba'in Masalah aqidah, Syariah, \& Akhlaq, Bandung: Penerbit Marja, 2001.

Mustafa Edwin dan Ranti Williasih, "Profit Sharing dan Moral hazard dalam Penyaluran Dana Pihak Ketiga Indonesia" Jurnal Ekonomi dan Pembangunan Indonesia. Vol IIV. No. II. (2007). http://staff.ui.ac.id/system/files/users/mustafa.nasution/publica tion/bf b 1 c 433 profit sharing dan moral. mustafa e na sution ok.pdf (diakses pada tanggal 24 Oktober 2016)

Ramli,Soehatman. Pedoman Praktis Manajemen Risiko Jakarta: PT. Dian Rakyat, 2010.

Arifin. Zainu., Dasar-Dasar Manajemn Bank Syariah Jakarta: Pustaka Alfabet, 2005..

Idroes, Ferry N. Manajemen Risiko Perbankan ,Jakarta: Rajawali Pers, 2008.

Rivai,Veitzhal. dkk. Bank and Financial Institution Management: Conventional and Syar'I System, Jakarta:RajaGrafindo Persada, 2007.

Rivai Veithzal. dan Andria Permata Veithzal, Islamic Financial Management (Teori, Konsep, dan Aplikasi Lembaga Keuangan, Nasabah, Praktisi, dan Mahasiswa), h. 630.

Republik Indonesia, Peraturan Presiden Republik Indonesia Nomor 9 Tahun 2009 Tentang Lembaga Pembiayaan, Bab I, Pasal 1.

Siamat, Dahlan. Manajemen Lembaga Keuangan Edisi II; Jakarta: Fakultas Ekonomi Universitas Indonesia. 2001.

Otoritas Jasa Keuangan, Peraturan Otoritas Jasa Keuangan Nomor 28/POJK.05/2014 Tentang Perizinan Usaha Dan Kelembagaan Perusahaan Pembiayaan, Bab I, Pasal 1.

Antonio, Muhammad Syafi'i. Bank Syariah dari Teori Ke Praktek Jakarta : Gema Insani bekerjasama dengan Tazkia Cendikia, 
2001.

Muhammad, Manajemen Bank Syariah (Yogyakarta; Ekonisia, 2005), h. 260 .

Lexy J, Moleong. Metodologi Penelitian Kualitatif Cet. X; Bandung: Remaja Rosdakarya, 2003.

Basrowi dan Suwandi, Memahami Penelitian Kualitatif Jakarta: Rineka Cipta, 2008.

Sugiyono, Metode Penelitian Kuantitatif dan kualitatif dan $R \& D$ Bandung: Alfabeta, 2009.

Koentjoroningrat, Metode-Metode Penelitian Masyarakat Jakarta: Gramedia, 1991.

Ahmad,A. Kadir. Dasar-Dasar Metodologi Penelitian Kualitatif Makassar: Indobis Media Centre, 2003.

Fahmi, Irfan. Manajemen Risiko Teori, Kasus dan Solusi Bandung: Penerbit Alfabeta, 2016.

Komite Nasional Kebijakan Governance, Pedoman Penerapan Manajemen Risiko Berbasis Governance, Jakarta: KKNG, 2012.

*Dosen UIN Alauddin Makassar 